OPEN ACCESS

Edited by:

Huiping Zhang,

Institute of Geology, China

Reviewed by:

Lin Xu,

China Three Gorges University, China

Lei Wu,

Zhejiang University, China

${ }^{*}$ Correspondence:

Qiming Zhao

zhaoqm16@lzu.edu.cn

Xiaofei $\mathrm{Hu}$

feixhu@/zu.edu.cn

Specialty section:

This article was submitted to Structural Geology and Tectonics, a section of the journal Frontiers in

Earth Science

Received: 30 November 2021 Accepted: 24 December 2021

Published: 02 February 2022

Citation:

Pan B, Zhao Q, Hu X, Zhang J and Chen D (2022) Uplift and Expansion of the North Qilian Shan Recorded by Detrital Fission Tracks in the Jiudong

Basin, NW China.

Front. Earth Sci. 9:826104. doi: 10.3389/feart.2021.826104

\section{Uplift and Expansion of the North Qilian Shan Recorded by Detrital Fission Tracks in the Jiudong Basin, NW China}

\author{
Baotian Pan, Qiming Zhao*, Xiaofei Hu*, Jiaxin Zhang and Dianbao Chen \\ Key Laboratory of Western China's Environmental Systems (Ministry of Education), College of Earth and Environmental Sciences, \\ Lanzhou University, Lanzhou, China
}

The North Qilian Shan, located in the northeastern front of the Tibetan Plateau, is an ideal region to study the expansion process of the plateau, which is not clearly revealed due to the lack of direct evidence and an accurate age control. In the Jiudong Basin (foreland basin of the North Qilian Shan), a continuous late Cenozoic sedimentary sequence and a reliable chronostratigraphic framework (post-7 Ma) provide us the material to study this process. In this study, we first analyzed the provenance changes of the sediment by detrital apatite fission track age distributions and apatite particle textures. The result shows that the first provenance change occurred at 4.6-3.6 Ma, when the sediment source changed from the southern to the northern parts of the North Qilian Shan, and it indicates that the North Qilian Shan Fault had propagated to its modern location. The second provenance change occurred at 3.0-2.4 Ma, at when the Yumu Shan and its south region began to provide sediments for the Jiudong Basin, and it indicates that the tectonic deformation in the North Qilian Shan had expanded to the North Yumu Shan Fault. Our finding suggests that two significant expansion events happened since the Pliocene for the North Qilian Shan.

Keywords: North Qilian Shan, Jiudong Basin, apatite fission track, provenance change, Tibetan Plateau expansion

\section{INTRODUCTION}

The collision of the Indian and Eurasian plates caused the uplift and expansion of the Tibetan Plateau, which has a profound impact on the geomorphic evolution of Asia and the global climate change (e.g., Molnar et al., 1993; An et al., 2001; Pan et al., 2004; Xu et al., 2011). The northeastern margin (the Qilian Shan) of the Tibetan Plateau represents the most-front for the ongoing expansion (Tapponnier et al., 2001), and how this margin grows or expands is key to understanding the formation dynamics for the entire plateau (Burchfiel et al., 1989; Métivier et al., 1998; Yin and Harrison, 2000; Clark, 2012). Although the intense uplift of the Qilian Shan that began at 15-10 Ma is supported by multiple evidences (Zheng et al., 2010; Zheng et al., 2017; Wang et al., 2016; Wang et al., 2020; Zhuang et al., 2018; Pang et al., 2019a; Pang et al., 2019b), the detailed expanding process is still in debate (e.g., Cheng et al., 2019; Hu et al., 2021). Especially for the northward expanding of the North Qilian Shan (e.g., Tapponier et al., 1990; Zheng et al., 2013), several studies tried to answer this question. From apatite fission track (AFT) age distribution across the main range, Pang et al. (2019a) suggest a sequence of thrust faults prograde to the north since Late Miocene ( $\sim 10 \mathrm{Ma})$. To the north of the main range, paleomagnetic studies on the exposed Cenozoic strata in the Jiuxi Basin suggest 
that the thrust system started to develop in the basin during 4.9-2.6 Ma (Fang et al., 2005) or at $3.0 \mathrm{Ma}$ (Chen et al., 2006; Zhao et al., 2017). In the Jiudong Basin, Plio-Quaternary deformation of the Yumu Shan is also indicated by coarsegrained sediments at $3.0 \mathrm{Ma}$ ( $\mathrm{Hu}$ et al., 2019a), the faster cooling at $\sim 4.0 \mathrm{Ma}$ from AFT thermal modeling (Wang et al., 2018), the estimation of 4.6 to $2.0 \mathrm{Ma}$ by dividing the structural relief with the current fault slip rate (Palumbo et al., 2009; Hu et al., 2019b), and the unconformity between 0.8 and $0.9 \mathrm{Ma}$ (Liu et al., 2011). The frame of a northward sequence for the thrust fault across the North Qilian Shan has been found; however, the clear process is still not revealed. This fact is mostly due to a lack of direct evidence from the range, such as the thermochronology method, and the Plio-Quaternary uplift is insufficient to expose complete annealing rocks to the surface (George et al., 2001; Jolivet et al., 2001). It is also due to the great uncertainty in calculating uplift time by recent deformation rate and in estimating the age for the unconformity where the material for dating is missing due to erosion. Therefore, direct evidence and accurate age control are needed to reveal a continuous expansion process of the North Qilian Shan.

In the Jiudong Basin, previous research obtained a continuous late Cenozoic (post-7 Ma) sedimentary sequence from the $\mathrm{MH}$ drill core, and it provided a detailed lithostratigraphic and chronostratigraphic framework for the sediments ( $\mathrm{Hu}$ et al., 2019a). This provides us an ideal material to find the direct evidence for the northward expansion of the range. In this study, detrital AFT ages (Gallagher et al., 1998; Garver et al., 1999; Bernet, 2001) and apatite particle textures are used for a provenance study, and then we use the change of the provenance to reveal the expansion process of the North Qilian Shan from late Miocene to the Pliocene.

\section{Geological Setting}

In the northern front of the Qilian Shan, the foreland basins extend southeast to northwest with a length of $1,000 \mathrm{~km}$, and the basin is divided into several sub-basins, the Jiuquan, the Minle, and the Wuwei basins (EGPGYO, 1989; Fang et al., 2005; Wang et al., 2016). The Jiuquan basin can be separated by the Wensu Shan into two parts, the Jiudong Basin in the east and the Jiuxi Basin in the west. The Jiudong Basin has been a depressed area since the Neogene and is filled with $>3,000$-m-thick terrigenous clastic sediments (Li and Yang, 1998; Bovet et al., 2009). Along the southern edge of the basin close to the Qilian Shan, Cenozoic sedimentary rocks overlie Paleozoic metasedimentary rocks. Cenozoic sediments can be divided into the following stratigraphic formations (Fang et al., 2005): Eocene-Oligocene Huoshaogou formation and Oligocene Baiyanghe formation, consisting of fluvio-lacustrine red beds with fine conglomerate to mudstone intercalated by playa gypsum beds; Miocene Shulehe formation, consisting of fluvio-lacustrine gray and brown fine conglomerate, sandstone, and siltstone; the Quaternary Yumen conglomerates, Jiuquan conglomerates, and Gobi conglomerates from bottom to top. The Quaternary conglomerates are characterized by poor roundness in general. $\mathrm{MH}$ drill core $\left(3927^{\prime} 47.5^{\prime \prime} \mathrm{N}, 9926^{\prime} 00.1^{\prime \prime} \mathrm{E}\right.$, elevation: $1,387 \mathrm{~m}$ ) is located at the eastern Jiudong Basin and downstream of the Maying River and the Bailang River. The drilling depth was $554 \mathrm{~m}$, and the sediments are dominated by sand and silt, with occasional interbedded layers of mediumcoarse sands, gravels, or clays. The sedimentary sequence of $\mathrm{MH}$ drill core could be divided into four stratigraphic units based on lithology, sedimentary texture, structure, and their vertical associations (Hu et al., 2019a). Unit 1 (554-465.3 m, 7.0-5.2 Ma) is dominated by clay silt, silt, and sandy silt, which are intercalated with thin and medium bedded sand layers. The facies assemblage suggests the depositional environment is a delta front or shallow lake. Unit 2 (465.3-395.6 m, 5.2-4.1 Ma) mainly consists of alternating layers of thin to medium bedded silt and sand. This unit is interpreted as a delta plain or littoral lake facies. Unit 3 (395.6-292.5 m, 4.1-3.0 Ma) consists of alternating layers of medium to thick bedded sand and silt, and this unit is interpreted as meandering river facies. The unit 4 $(292.5-0 \mathrm{~m}, 3.0-0 \mathrm{Ma})$ is dominated by thick sand layers intercalated with several medium to thick bedded gravel layers and thin layers of clay and silt. It is inferred that this unit was deposited within a braided river environment ( $\mathrm{Hu}$ et al., 2019a).

The thick late Cenozoic deposition in Jiuquan basin is controlled by the uplift and erosion of the Qilian Shan (Figure 1A, B). The Qilian Shan had experienced a long and complex tectonic history, including early Paleozoic oceanic sutures and continental collision events during the late Paleozoic, Mesozoic, and Cenozoic intraplate orogeny events (Li, 2003; Yang et al., 2007; Chen et al., 2019). The Cenozoic deformation process of the Qilian Shan started to occur in the early Cenozoic (Yin et al., 2002), with rapid exhumation during the Oligocene (Wan et al., 2011; Zhuang et al., 2018) and the Miocene (Wang et al., 2017; Zhuang et al., 2018). Stratigraphy studies suggest that the Qilian Shan expanded southwards to the Qaidam basin during 12-7 Ma (Wang et al., 2017; Pang et al., 2019b). At the north part of the Qilian Shan, a growing number of low-temperature thermochronology evidence indicate that significant orogeny began in the Miocene (Zheng et al., 2010; Baotian et al., 2013; Li et al., 2013; Qi et al., 2016; Zheng et al., 2017; Pang et al., 2019a; Yu et al., 2019; Li et al., 2020). The conglomerate accumulation in the south Jiuquan basin during 4.5-0.9 Ma or 3.6-0.9 Ma (Zhao et al., 2001; Fang et al., 2005) suggests that the North Qilian Shan had reached a high topographic relief in Pliocene. The basin-ward growth of the deformation system to the north of the main range is represented by the uplift of the Yumu Shan that began at 2.5-4 Ma (Palumbo et al., 2009; Wang et al., 2018; Hu et al., 2019a; Hu et al., 2019b) and the formation of the Laojunmiao Anticline that began at $3.66 \mathrm{Ma}$ (Fang et al., 2005). The evidence probably indicated that the intense uplift of the Qilian Shan started during the Miocene and the mountains began to expand to the foreland basin from late Miocene to the Pliocene. However, due to the lack of direct evidence, the specific uplift and expansion process of the Qilian Shan are not clear. 


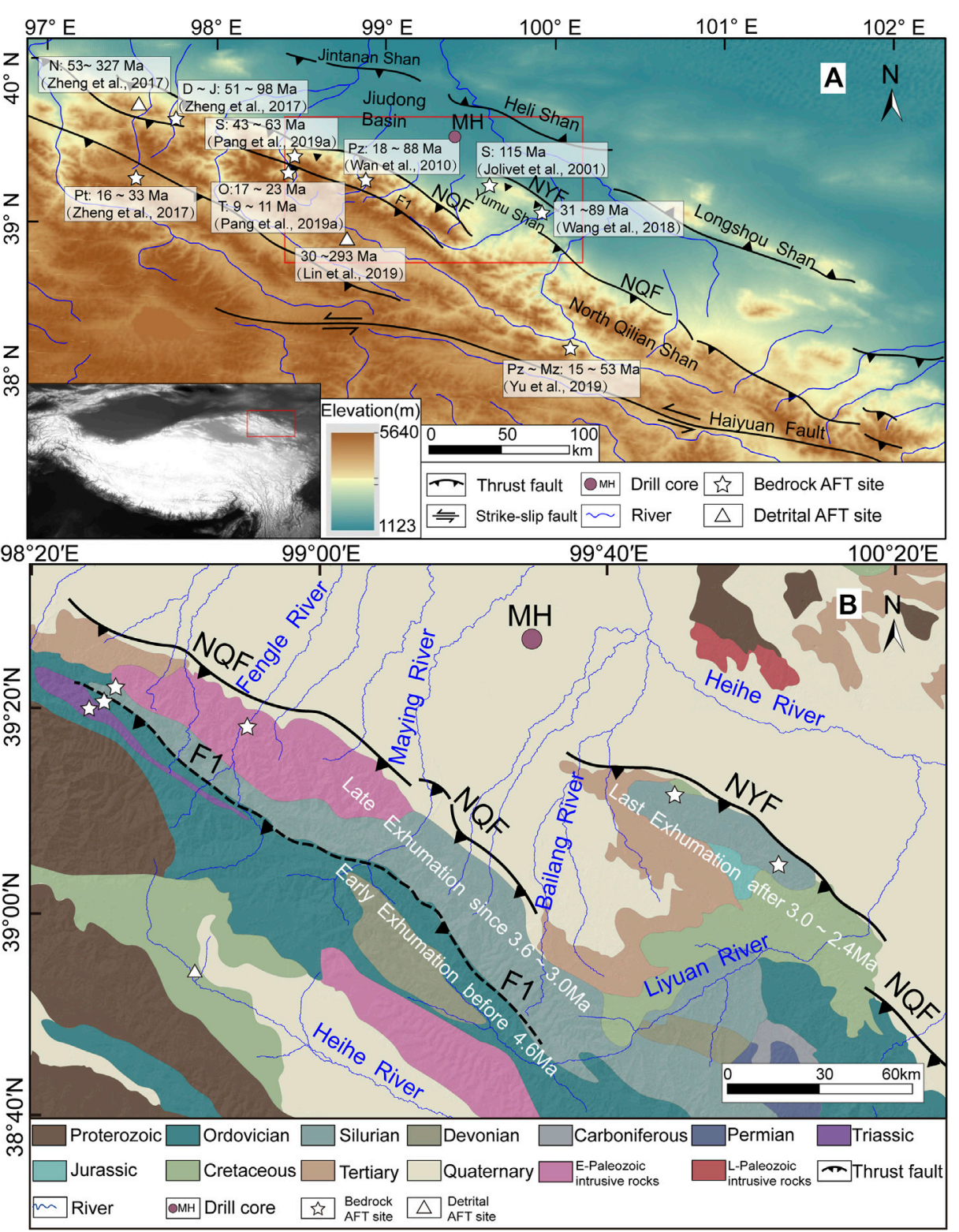

FIGURE 1 | (A) Topography of North Qilian Shan and the Hexi Corridor basin. Also shown is the distribution of major active faults, NQF-North Qilian Fault and NYF-North Yumu Shan Fault (Yuan et al., 2013), and major rivers. The numbers in the rectangles show AFT ages and the lithology unit where the sample was taken from: Pt-Proterozoic, Pz-Paleozoic, O-Ordovician, S-Silurian, D-Devonian, Mz-Mesozoic, T-Triassic, J-Jurassic, and N-Tertiary. (B) Simplified geologic map of the Jiudong Basin and the surrounding area (modified from the 1:500,000 geologic map of China).

\section{MATERIALS AND METHODS}

In this study, we adopted the external detector method (Gleadow and Lovering, 1977) to obtain the AFT age of the sample. The standard equation to calculate the age is

$$
t=\frac{1}{\lambda_{d}} \ln \left[\frac{\lambda_{d} \phi \sigma I \rho_{s}}{\lambda_{f} \rho_{i}}+1\right]
$$

In Eq. 1, $\lambda_{d}$ is the total decay constant of ${ }^{238} \mathrm{U}\left(\lambda_{d}=1.55125\right.$ $\times 10-10 \mathrm{a}-1$, Steiger and Jäge, 1977), $\lambda_{f}$ is the spontaneous fission constant, $\rho_{s}$ is the spontaneous fission track density, $\rho_{i}$ is the induced fission track density, and "I" is the ratio of ${ }^{235} \mathrm{U}$ and ${ }^{238} \mathrm{U}$ under natural conditions, and has a value of $7.2527 \times 10^{-3}$ (Cowan and Adler, 1976). $\phi$ is the thermal neutron flux; $\sigma$ is the effective area irradiated by thermal neutrons, as a constant. Among the aforementioned parameters, only the values of $\lambda_{d}$ and I are universally recognized, but the value of $\lambda_{f}$ is still controversial at present. Besides, it is very difficult to determine the thermal neutron flux $\phi$. Therefore, zeta $(\zeta)$ parameter calibration was proposed to calculate the AFT age (Hurford and Green, 1981). This method could eliminate the 
error caused by the uncertainty of thermal neutron irradiation and spontaneous fission track decay constant $\lambda_{f}$.

In Eq. 1, let $\zeta=\frac{\phi \sigma I}{\lambda_{f} \rho_{d}}$, then Eq. 1 can be transformed into equation

$$
t=\frac{1}{\lambda_{d}} \ln \left[\lambda_{d} \zeta \frac{\rho_{s}}{\rho_{i}} \rho_{d}+1\right]
$$

Put the standard apatite sample with a certain age of $t_{S T D}$ into the reactor together with a uranium glass detector, and thermal neutron irradiation produced induced fission track in the standard apatite and uranium glass detector. Calculate the spontaneous fission track density $\mathrm{A}$ and the induced fission track density $\mathrm{B}$ of the standard apatite sample and the fission track density of uranium glass detector. The value of $\zeta$ could be obtained by equation

$$
\zeta=\frac{\mathrm{e}^{\lambda_{d} t_{S T D}}-1}{\lambda_{d}\left(\rho_{s} / \rho_{i}\right)_{S T D} \rho_{d}}
$$

Substituting the obtained zeta $(\zeta)$ parameter into Eq. 2, we could calculate the AFT age of the geological sample.

In this study, we collected 10 samples at different depths from the $\mathrm{MH}$ core. These samples are taken from different sedimentary facies or at the position where the facies significantly change. By correlating to the magnetostratigraphic analysis ( $\mathrm{Hu}$ et al., 2019a), the depositing age for each sample is determined and they range from 5.9 to $0.045 \mathrm{Ma}$. Each sample mainly consists of fine and medium sands and has a weight of $2-3 \mathrm{~kg}$. All samples were collected from the sand layers. The bulk sample was washed and separated by magnetic and heavy liquid to purify heavy minerals, and then pure apatite crystals were manually picked. The selected apatite crystals were mounted on a slide with epoxy resin and polished to expose their internal surface. The polished mount was etched with $\mathrm{HNO}_{3}$ for $20 \mathrm{~s}$ at $21^{\circ} \mathrm{C}$ to reveal the spontaneous fission track. All samples were dated by the external detector method (Hurford and Green, 1981); low-U mica external detectors covered the standard sample (Durango apatite with age of $31.4 \pm 0.5 \mathrm{Ma}$ ), apatite mounts, and glass dosimeters (IRMM$540 \mathrm{R}$ ), and then they were irradiated by the reactor at Oregon State University. After irradiation, mica detectors were etched in $40 \% \mathrm{HF}$ at $20^{\circ} \mathrm{C}$ for $40 \mathrm{~min}$ to reveal the induced fission tracks. Tracks were measured using the Auto scan Professional Automated System in the Key Laboratory of Western China's Environmental Systems (Ministry of Education), Lanzhou University. Spontaneous and induced fission track densities of all samples (including standard samples) and fission track densities of uranium glass detectors were calculated. The zeta

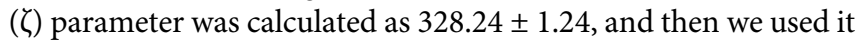
to obtain AFT ages of all samples.

Because the clastic deposits mostly come from multiple provenances, the AFT central age of detrital sample would be a mixed age, which does not have clear geological significance (Braun et al., 2006). For a bulk age data, the $\mathrm{p}\left(\chi^{2}\right)$ test (Galbraith and Green, 1990) is performed to determine whether there are unique or multiple age components. Samples fail the $\mathrm{p}\left(\chi^{2}\right)$ test, the $\mathrm{p}\left(\chi^{2}\right)$ probability less than $5 \%$, indicating that the sample contains several age components. In such case, Density Plotter
(Spencer et al., 2014), a program integrated mathematical fitting method, could be used to obtain the best-fitting age peaks of different components. The lag time, which is defined as the AFT fitting age peak minus the depositional age of sample (Garver et al., 1999), was introduced to measure the time from closure depth in the range to the deposit region of basin (Bernet, 2001). Generally, progressively shortened lag time indicates enhanced tectonic activity and accelerated exhumation rate of the source region, whereas constant lag time indicates that the exhumation rate of the source region is steady. Another special case is that a stable or decreasing lag time increases suddenly over a short period, and the depositional age corresponding to the overturn point could be the time when the sediment recycled (Garver et al., 1999; Zheng et al., 2017).

In general, unweathered euhedral apatite particle is a hexagonal column; the shape is column or regular hexagon under the microscope. For terrigenous clastic sediments, the roundness and surface textures of apatite particles will change due to abrasion, mechanical crushing, and chemical weathering (Liu, 1980; Zhu, 2008; Andò et al., 2012). The roundness of detrital apatite particles usually becomes better with the increase of transporting distance and time, and the content of the euhedral particles decreases. Aiming to identify source differences for the samples, we measured the number of euhedral apatite particles and the roundness of apatite particles of each sample under the microscope (Figure 2), according to the catalog for optical analysis of corrosion of heavy minerals (Andò et al., 2012) and the roundness scale for sedimentary particles (Powers, 1953). The number of total measured apatite particles were greater than 75 in most samples, except MH1(36), MH4(58), and MH7(51).

\section{RESULTS}

The AFT age results of 10 samples are shown in Table 1. The single grain AFT ages of all samples range from 35 to $324.5 \mathrm{Ma}$, and most of them were distributed in the range of 100-180 Ma. According to the age distribution, the samples can be divided into three sections (Figure 3D). The lower section includes two samples from 5.9 to $4.6 \mathrm{Ma}$, and AFT ages are mostly distributed in 60-160 Ma; the middle section includes three samples from 3.6 to $3.0 \mathrm{Ma}$, and AFT ages are mostly distributed in 100-180 Ma; and the upper section includes five samples from 2.4 to $0 \mathrm{Ma}$, and AFT ages have a wider distribution in 60-300 Ma. After 3.0 Ma, apatite grains with AFT age older than $200 \mathrm{Ma}$ began to emerge. The apatite grain roundness (Figure 3E) and crystal morphology (Figure 3F) also show the change. From 5.9 to $4.6 \mathrm{Ma}$, apatite particles have moderate roundness (with certain number of very-rounded particles), and the euhedral apatite particle content is about 7\%. During 3.6-3.0 Ma, apatite particles have worse roundness (with large amount of sub-angular particles and no very-round particles), and the content of euhedral apatite particles is the highest of $10-12 \%$. From $2.4 \mathrm{Ma}$ to present, the five samples have best roundness (rounded particles dominant and with very-round particles), and the content of euhedral apatite particles is the lowest at $3-5 \%$. 


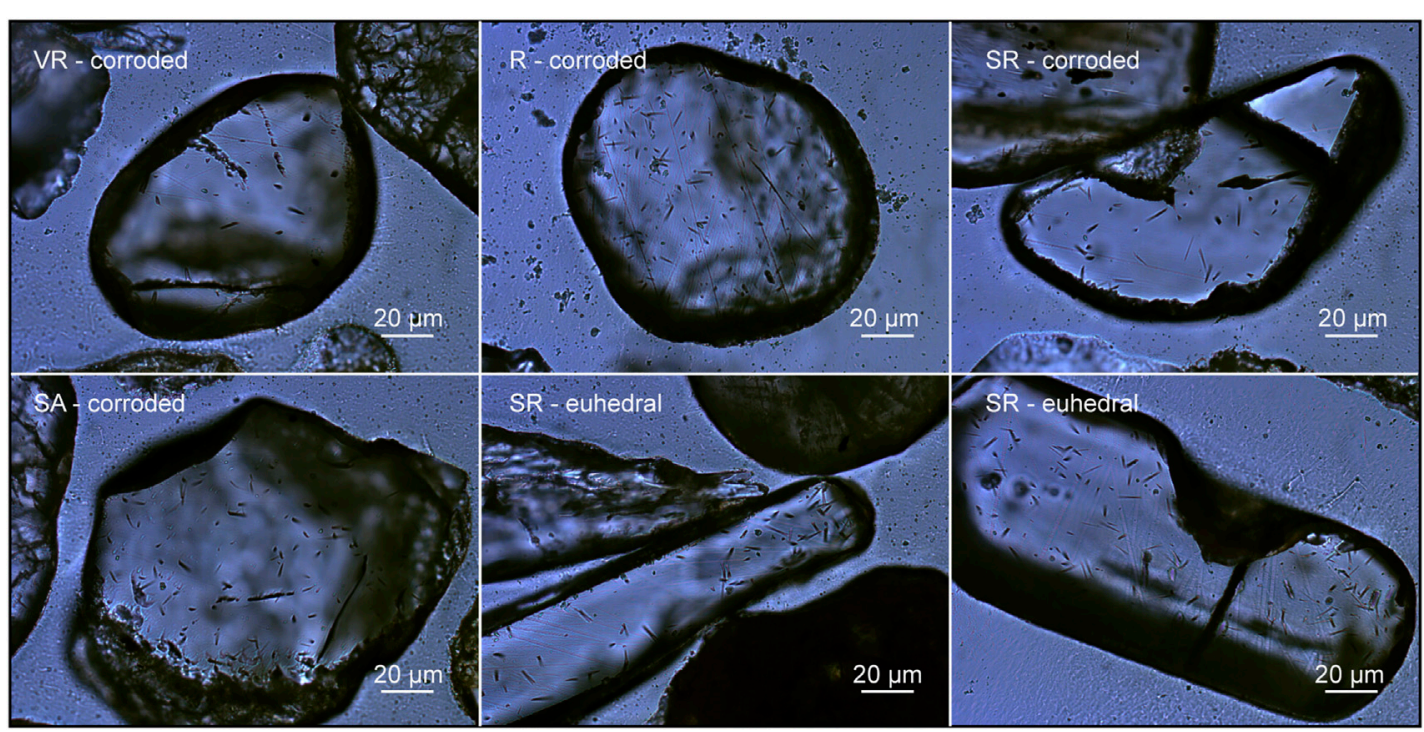

FIGURE 2 | Roundness and crystal textures characteristics of apatite particles.

TABLE 1 | Apatite fission track data from the $\mathrm{MH}$ drill core

\begin{tabular}{|c|c|c|c|c|c|c|c|c|c|c|}
\hline Sample & $\begin{array}{l}\text { Depth } \\
\text { (m) }\end{array}$ & $\begin{array}{c}\text { D age } \\
\text { (Ma) }\end{array}$ & $\mathbf{N}$ & $\begin{array}{c}\text { Age range } \\
\text { (Ma) }\end{array}$ & $\begin{array}{l}\text { Central } \\
\text { age (Ma) }\end{array}$ & $P\left(\chi^{2}\right)$ & P1 (Ma) & P2 (Ma) & P3 (Ma) & P4 (Ma) \\
\hline $\mathrm{MH} 1$ & 7.3-8.2 & 0.045 & 36 & 43.3-283.2 & $118.1 \pm 9.5$ & 0 & $67.5 \pm 6.9$ & $117.0 \pm 14.0$ & - & $196 \pm 22$ \\
\hline $\mathrm{MH} 2$ & $97.6-100.1$ & 0.6 & 76 & $51.1-282.2$ & $148.8 \pm 5.9$ & 0 & $59.1 \pm 7.9$ & $103.0 \pm 10.0$ & - & $172 \pm 12$ \\
\hline $\mathrm{MH} 3$ & $191.7-194.2$ & 1.3 & 78 & $40.2-288.4$ & $96.4 \pm 4$ & 0 & $62.7 \pm 7.4$ & $108.0 \pm 11.0$ & - & $272 \pm 74$ \\
\hline $\mathrm{MH} 4$ & $222.1-224.7$ & 1.6 & 58 & 53.8-233.0 & $127.8 \pm 5.8$ & 0 & $69.0 \pm 10.0$ & $109.0 \pm 15.0$ & - & $158 \pm 14$ \\
\hline $\mathrm{MH} 5$ & $260.1-261.4$ & 2.4 & 76 & $35-324.5$ & $104.2 \pm 4.5$ & 0 & $52.6 \pm 6.2$ & $108.5 \pm 8.7$ & - & $208 \pm 33$ \\
\hline $\mathrm{MH} 6$ & 289.7-291.4 & 3.0 & 76 & 67.5-190.5 & $137.6 \pm 4$ & 0.99 & - & - & $137.6 \pm 4$ & - \\
\hline $\mathrm{MH} 7$ & 328.3-330.8 & 3.4 & 51 & $50.2-197.2$ & $131.7 \pm 6.7$ & 0 & $70.3 \pm 9.5$ & - & $144 \pm 11$ & - \\
\hline $\mathrm{MH8}$ & 348.3-350.8 & 3.6 & 83 & $67.1-170.6$ & $129 \pm 3.6$ & 0.35 & - & & $129 \pm 3.6$ & - \\
\hline MH9 & $437.9-440.5$ & 4.6 & 82 & $44.2-161.6$ & $100.8 \pm 3.8$ & 0 & $62.7 \pm 7.6$ & $116.0 \pm 11.0$ & - & - \\
\hline $\mathrm{MH} 10$ & 511.8-513.3 & 5.9 & 78 & $46.5-171.7$ & $112 \pm 4.2$ & 0 & $66.3 \pm 7.9$ & $121.3 \pm 9.3$ & - & - \\
\hline
\end{tabular}

$\mathrm{P}\left(\chi^{2}\right)$ test result shows that eight of 10 samples did not pass $\mathrm{p}$ $\left(\chi^{2}\right)$ test (Figure 4), suggesting they have multiple age components and provenances. For the two samples passing the test, MH6 and MH8, we considered that they contain only one age component. Although the sample MH7 did not pass the $\mathrm{p}\left(\chi^{2}\right)$ test, its age distribution is relatively narrower and most age data are concentrated in the range similar to MH6 and MH8, and thus it can be grouped with MH6 and 8, which have a single provenance. We decomposed the observed age distributions into four bestfitting age component peaks, P1 (52.6-70.3 Ma), P2 (103-121 Ma), P3 (129-144 Ma), and P4 (>158 Ma). After the decomposition, the different age component combination for these samples (Table 1) shows a similar pattern as previous separation of the three parts (Figure 3). The four age components also suggest that these apatite grains in the basin sediment came from four different sources.

Since the content of $\mathrm{P} 3$ and $\mathrm{P} 4$ component is relatively older, which may have undergone recycles in the geological process, it cannot reflect the recent uplifting process of the mountain. Therefore, we only consider the younger components to analyze the pattern of the lag time. As shown in Figure 5, the lag time of P1 and P2 showed a trend of decreasing during 5.9-2.4 Ma and a trend of increasing since $2.4 \mathrm{Ma}$. The depositional age corresponding to the inflection point is $2.4 \mathrm{Ma}$, suggesting that the previous sediments were recycled.

\section{DISCUSSION}

\section{The Provenance Changes of the Sediment}

The bottom of the $\mathrm{MH}$ core is $554 \mathrm{~m}$, considered the geothermal gradient of Jiuquan basin that ranged $25-30^{\circ} \mathrm{C} / \mathrm{km}$ (Ren et al., 2000), and the temperature of the sediment is far from the depth of annealing for AFT of $60-120^{\circ} \mathrm{C}$ (Wagner et al., 1989). Thus, we believe that all samples in this study did not suffer annealing after deposition, and their AFT ages reflect the cooling age for the provenance of the sediment.

Modern drainage pattern in the Jiudong Basin (Figure 1B) indicates that the modern river for transporting sediments into the $\mathrm{MH}$ core includes the Maying River, two smaller rivers to the east of the Maying River, and probably the Bailang River. According to previous studies in the basin sediment (Pan et al., 2016; Hu et al., 2019a), no sediment from the Heihe 


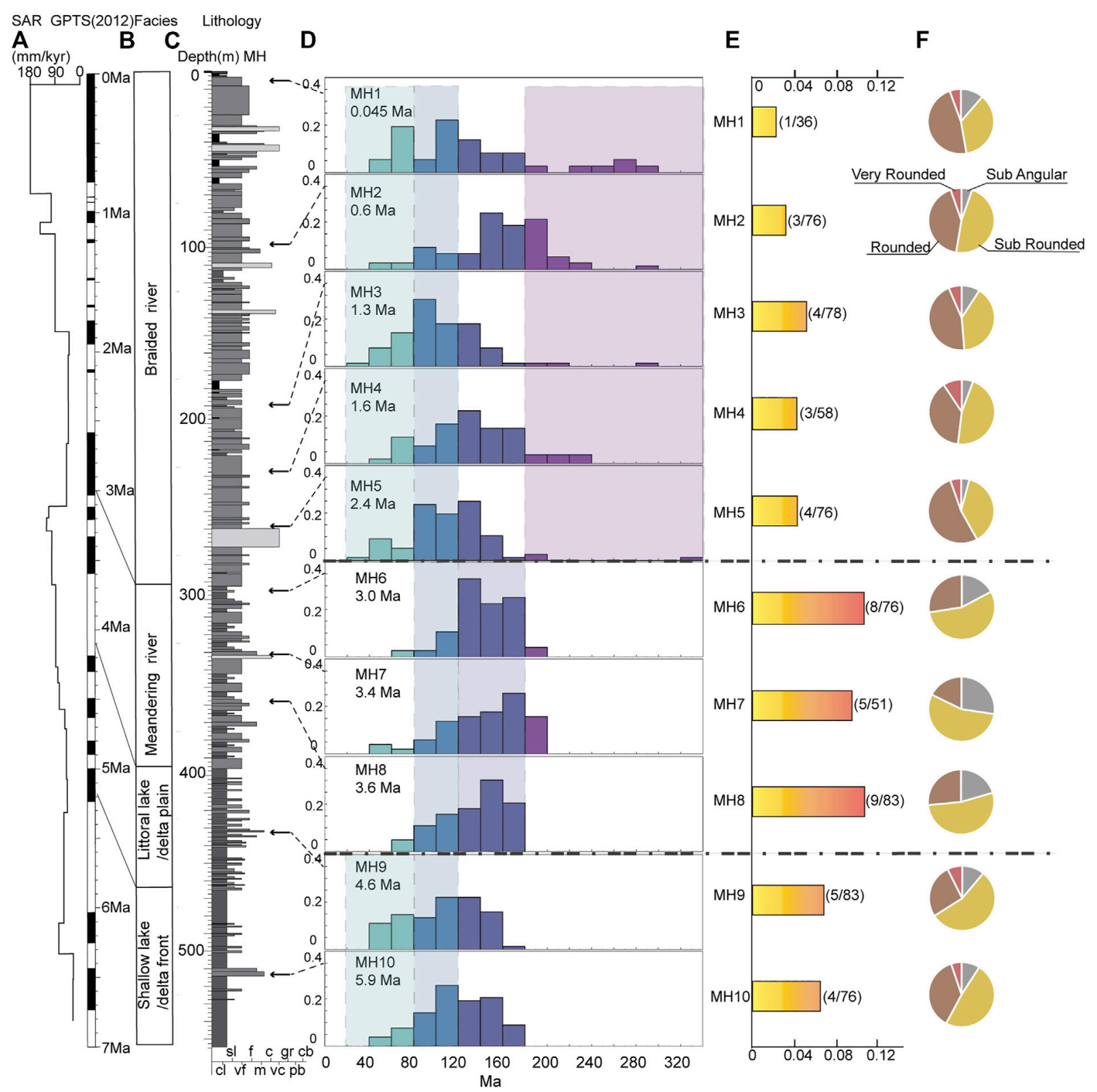

FIGURE 3 | (A) Comparison of the sediment accumulation rate (SAR). (B) Sedimentary facies. (C) Lithology: cl-clay; sl-silt; vf-very fine sand; f-fine sand; m-medium sand; c-coarse sand; vc-very coarse sand; gr-granule; pb-pebble; cb-cobble (Hu et al., 2019a). (D) The single grain age distribution. (E) The content of euhedral apatite particles (euhedral apatite particles/all observed apatite particles). (F) The roundness of apatite particles.

River was deposited in the MH core, so the source of the deposition can be constrained to the regions ranging from the Maying to the Bailang. During the recent period, 2.4-0 Ma, the AFT age distribution shows a wide range and multiple sources, which suggest it was not from a single river. For the samples in this stage, the roundness of apatite particles is very well and the content of euhedral apatite particles is very low (Figure 3), suggesting that the sediments had been transported over long distances or had experienced multiple transport-deposition processes. A distinguished pattern in this period is the appearance of apatite grains with ages older than $200 \mathrm{Ma}$. In the Qilian Shan range, samples containing AFT age older than $200 \mathrm{Ma}$ were reported from Tertiary strata in the Jiuxi Basin (Zheng et al., 2017) and modern sediments of the upper reaches of Heihe River (Lin et al., 2019), where the main exposed strata are the Cretaceous sandstones (Figure 1B). Among the possible sources for the $\mathrm{MH}$ core, only the Bailang River is draining the Cretaceous and Tertiary sediments in the Yumu Shan and its south range. Besides, the lag time inflection point suggested that the recycled sediments have appeared in $\mathrm{MH}$ core since $2.4 \mathrm{Ma}$, and it is consistent with the time of provenance change and the time of sedimentary facies change. Thus, the evidence indicates 


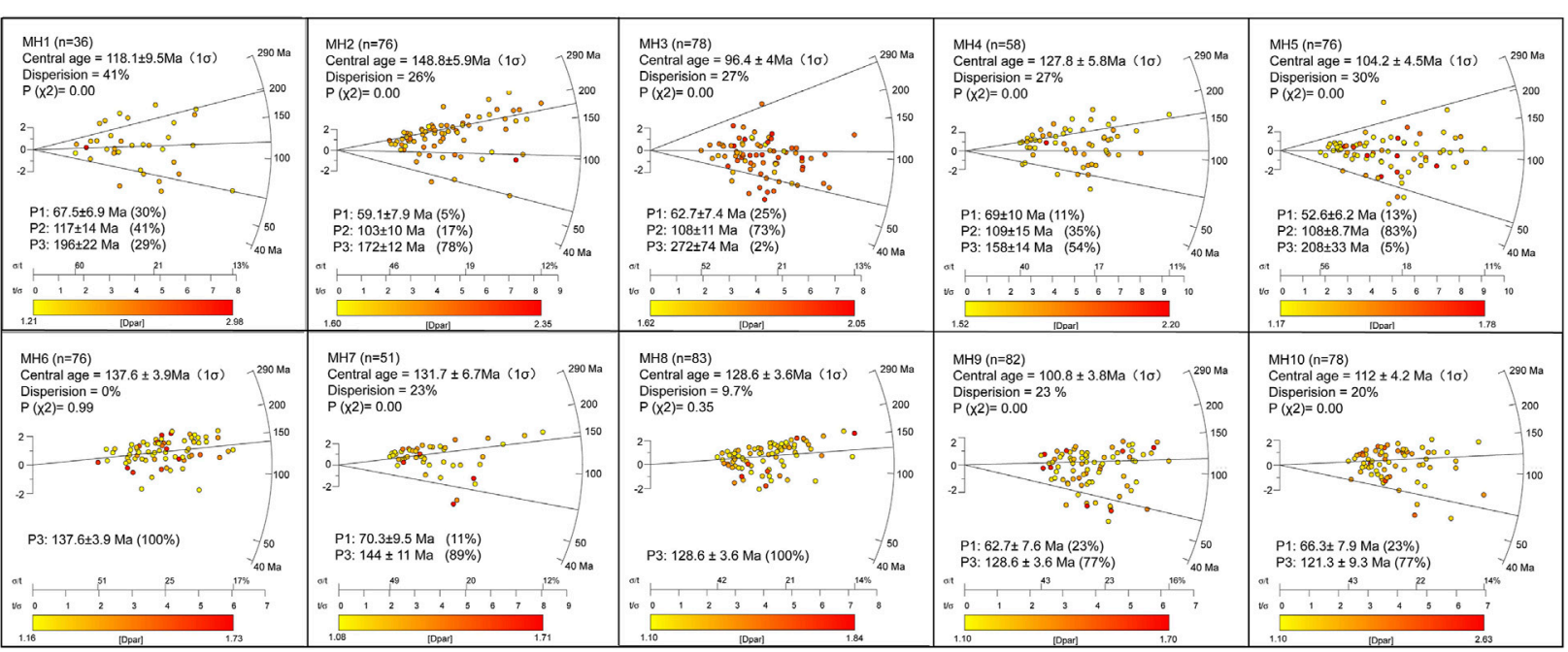

FIGURE 4 | Fitting age peaks by Density Plotter.

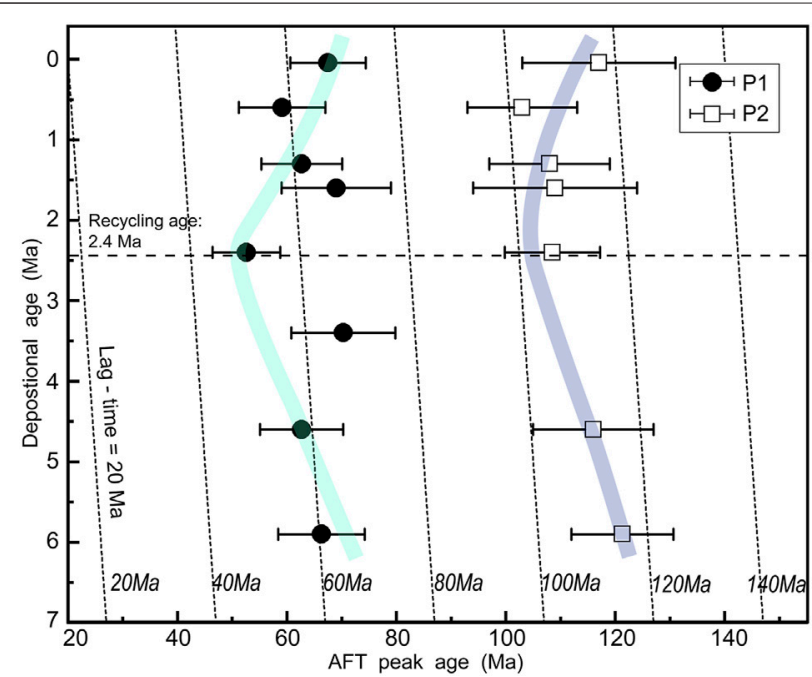

FIGURE 5 | Apatite fission track (AFT) fitting age peaks versus depositional age plot.

that the Yumu Shan range supplied sediments to the Jiudong Basin by the Bailang River during 2.4-0 Ma, and the North Qilian Shan also supplied sediments to the basin by the Maying River and the two smaller rivers.

During the period of 3.6-3.0 Ma, the single component pattern of AFT ages is greatly different with the upper and the lower section (Figure 3 and Figure 4), suggesting a single source region different from the previous or late period. The roundness of apatite particles is poorer and the content of euhedral apatite particles is less than that of the other two sections; it indicates that the sediments had not suffered intense weathering and abrasion during the process of erosion and transportation. These evidences suggest that apatite particles in the section were mostly from a simple source and transported by a relatively small drainage that originated in front of the North Qilian
Shan. The simple bedrock of Silurian (Figure 1B) drained by the two smaller rivers is the most suitable source. To the west of the studied region, the AFT study across the range of the North Qilian Shan suggests that the Silurian rock in the north has older age than other exposed rocks to the south attributing to a later activation of the northern thrust (Pang et al., 2019a). Comparing with the Maying River draining a large area containing Proterozoic to Devonian rock, rivers only draining the Silurian rock would supply the sediments to the Jiudong Basin, probably the two smaller rivers and the Bailang River without the drainage area of the Yumu Shan range.

During the period of 5.9-4.6 Ma, AFT ages are distributed in a relatively younger range, and can be divided into two age components P1 and P2. These two components appear in all samples and with high content; it means that this provenance has continuously provided numerous sediments for the Jiudong Basin at least since 5.9 Ma. For the rocks to the south of the F1 fault, published AFT data of in situ bedrock (Jolivet et al., 2001; Guo et al., 2009; Wan et al., 2010; Li et al., 2013; Baotian et al., 2013; Qi et al., 2016; Zheng et al., 2017; Li et al., 2020) are mainly distributed in the range of 20-120 Ma, which is in agreement with the age range of two samples from 5.9 to $4.6 \mathrm{Ma}$ (Figure 3). The only possible river that brought these sediments is the Maying River, and thus we suggest that the provenance for the sediment during 5.9-4.6 Ma was the southern part of the North Qilian Shan, transported by a river similar to the modern Maying River.

\section{Northward Expansion of the North Qilian Shan}

Previous studies on basin sediments have found a coarsen-upward trend (Liu et al., 2011; Hu et al., 2019a), showing a northward propagation for the deposition system in recent $7 \mathrm{Ma}$, and our results infer a more clear dynamics for the propagation. The first change of the source for the sediment happened at 4.6-3.6 Ma, and this source change from the south to the north of the North Qilian Shan probably indicates the northward propagation of the thrust 


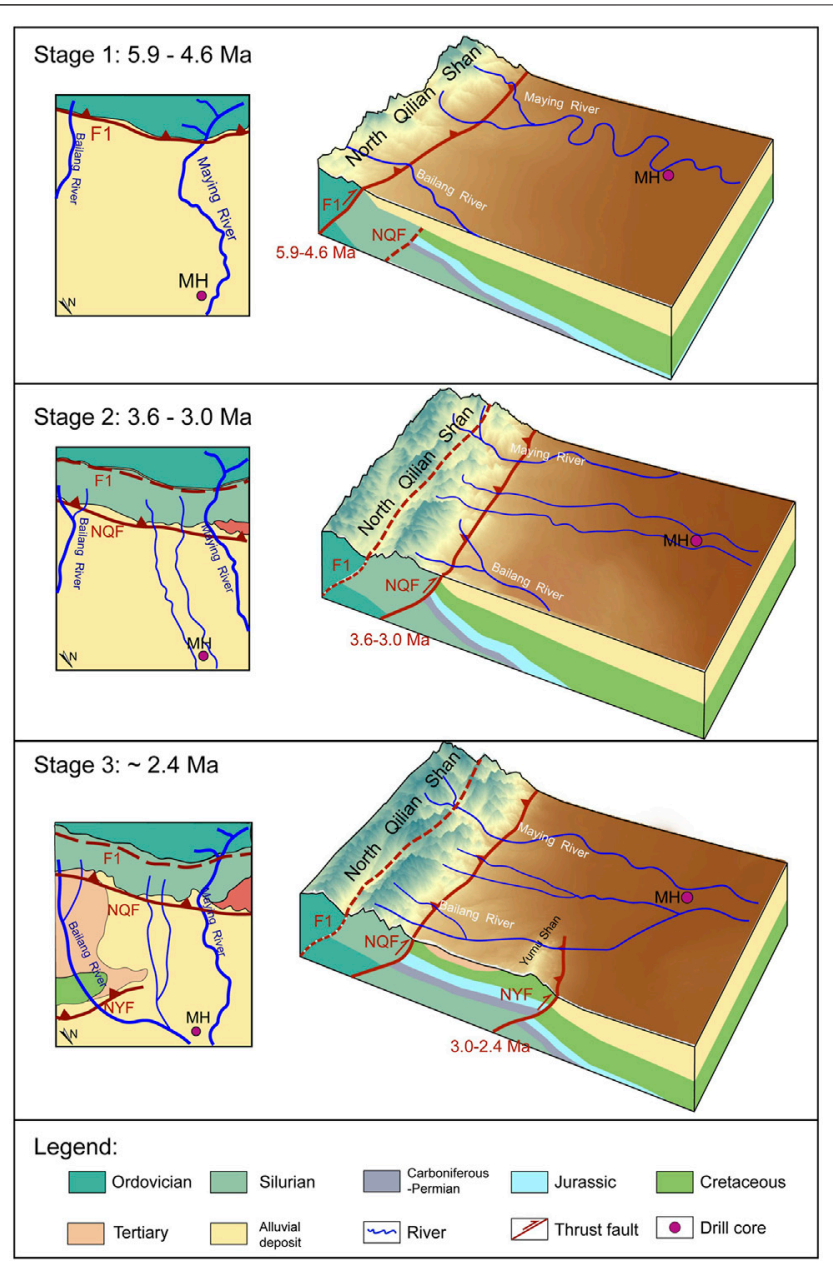

FIGURE 6 | The progressive deformational model of the North Qilian Shan during late Cenozoic. NQF_-North Qilian Shan Fault; NYF-North Yumu Shan Fault. Stratigraphic texture modified from the 1:500,000 geologic map of China (EGPGYO, 1989) and seismic sections in the Jiuquan Basin (Yang et al., 2007; Zuza et al., 2016).

fault, from the F1 to the modern NQF (Figure 1B and Figure 6). The activation of the NQF uplifted the Silurian rock and supplied the sediment to the Jiudong Basin. The second change of the source during 3.0-2.4 Ma indicates the uplift and erosion of the Yumu Shan range, and this situation was caused by the further northward propagation of the thrust system, from the NQF to the NYF.

The first propagation of the Qilian range at $4.6-3.6 \mathrm{Ma}$ corresponds to the large unconformity at 5.2-3.6 Ma in the depositing sequence at the western Yumu Shan (Liu et al., 2011), and also corresponds to the sedimentary phase change in basin center at $\sim 4.1 \mathrm{Ma}$ from lake/delta to rivers (Hu et al., 2019a). The second propagation to the Yumu Shan range at 3.0-2.4 Ma received various supports. AFT thermochronology on the Yumu Shan shows that it initiated growth during the Pliocene (Wang et al., 2018). At the $\mathrm{MH}$ core, the sedimentary environment changed from meandering river to braided river at 3.0 Ma, but the sediment accumulation rate abrupt decreased, indicating the uplift of the basin region (Hu et al., 2019a). In the Yumu Shan range, combining the geometry of the fault and fold with age control for the terraces (Palumbo et al., 2009), the rock uplift rate in the Yumu Shan was calculated as $1.2 \pm 0.1 \mathrm{~mm} / \mathrm{a}$, indicating an onset age of $2.5 \pm 0.5 \mathrm{Ma}$ for the uplift of the Yumu Shan (Hu et al., 2019b). Our investigation, in a more confident way, provides a narrower time range for the onset of the uplift of the Yumu Shan at 3.0-2.4 Ma.

\section{CONCLUSION}

Detrital AFT investigation of the $\mathrm{MH}$ drill core in the Jiudong Basin provides credible supplementary evidence to understand the clear expansion process of the North Qilian Shan. The single grain AFT age distribution, together with lag time of younger AFT fitting age peaks and the roundness and crystal surface texture of apatite particles, marked that two obvious provenance changes happened in the Jiudong Basin at 4.6-3.6 Ma and at 3.0-2.4 Ma. Combining published thermochronological data along the Qilian Shan and sedimentary records in the Hexi Corridor, we infer that the thrust fault propagated to the modern North Qilian Fault during 4.6-3.6 Ma and propagated to the North Yumu Shan Fault during 3.0-2.4 Ma.

\section{DATA AVAILABILITY STATEMENT}

The original contributions presented in the study are included in the article/supplementary material further inquiries can be directed to the corresponding authors.

\section{AUTHOR CONTRIBUTIONS}

BP: conceptualization, formal analysis, writing-original draft, visualization. QZ: conceptualization, formal analysis, investigation, writing-original draft, visualization. $\mathrm{XH}$ : investigation, formal analysis, investigation, writing-original draft. JZ: investigation, writing-review and editing. DC: investigation, writing-review and editing.

\section{FUNDING}

This work was supported by National Natural Science Foundation of China (41730637), the Second Tibetan Plateau Scientific Expedition and research program (STEP) (2019QZKK0704), National Natural Science Foundation of China 42001005, China Postdoctoral Science Foundation (2020M673529), and the Fundamental Research Funds for the Central Universities (lzujbky-2021-it38 and lzujbky-2018-it77).

\section{ACKNOWLEDGMENTS}

We are grateful to Jian Zhang, Jiakun Wu, and Yang Hong for their assistance in the treatment; and Xiuxi Wang and Jianzhang Pang for their assistance with the analysis of data. 


\section{REFERENCES}

Andò, S., Garzanti, E., Padoan, M., and Limonta, M. (2012). Corrosion of Heavy Minerals during Weathering and Diagenesis: A Catalog for Optical Analysis. Sediment. Geo. 280, 165-178. doi:10.1016/j.sedgeo.2012.03.023

An, Z., Kutzbach, J. E., Prell, W. L., and Porter, S. C. (2001). Evolution of Asian Monsoons and Phased Uplift of the Himalaya -Tibetan Plateau since Late MioceneTimes. Nature 411, 62-66. doi:10.1038/35075035

Baotian, P., Qingyang, L., Xiaofei, H., Haopeng, G., Zibian, L., Shaofei, J., et al. (2013). Cretaceous and Cenozoic Cooling History of the Eastern Qilian Shan, north-eastern Margin of the Tibetan Plateau: Evidence from Apatite FissionTrack Analysis. Terra Nova 25, 431-438. doi:10.1111/ter.12052

Bernet, M. (2001). Tracking the Evolution of Convergent Mountain Belts with Detrital Geo-Thermochronology. Metalurgija 43, 17-22. doi:10.1130/00917613(2001)029<0035:SSEOTE >2.0.CO;2

Bovet, P. M., Ritts, B. D., Gehrels, G., Abbink, A. O., Darby, B., and Hourigan, J. (2009). Evidence of Miocene Crustal Shortening in the North Qilian Shan from Cenozoic Stratigraphy of the Western Hexi Corridor, Gansu Province, China. Am. J. Sci. 309, 290-329. doi:10.2475/00.4009.02

Braun, J., Beek, P., and Batt, G. E. (2006). "Numerical Methods for the Interpretation of Thermochronological Data," in Quantitative Thermochronology (Cambridge, UK: Cambridge University Press).

Burchfiel, B. C., Quidong, D., Molnar, P., Royden, L., Yipeng, W., Peizhen, Z., et al. (1989). Intracrustal Detachment within Zones of continental Deformation. Geol 17, 748-752. doi:10.1130/0091-7613(1989)017<0448: idwzoc $>2.3$. co; 2

Chen, J., Wyrwoll, K. H., Lu, Y., Krapez, B., Wan, J., and Liu, J. (2006). Magnetochronology of the Yumen Conglomerates and Multi-Pulsed Folding and Thrusting in the Northern Qilian Shan (In Chinese). Quat. Sci. 26, 20-31. doi:10.3321/j.issn:1001-7410.2006.01.004

Chen, X., Shao, Z., Xiong, X., Gao, R., Liu, X., Wang, C., et al. (2019). Fault System, Deep Structure and Tectonic Evolution of the Qilian Orogenic Belt, Northwest China (In Chinese). Geo. China 46 (5), 995-1020. doi:10.12029/gc20190504

Cheng, F., Garzione, C. N., Mitra, G., Jolivet, M., Guo, Z., Lu, H., et al. (2019). The Interplay between Climate and Tectonics during the Upward and Outward Growth of the Qilian Shan Orogenic Wedge, Northern Tibetan Plateau. Ear.Sci. Rev. 198, 102945. doi:10.1016/j.earscirev.2019.102945

Clark, M. K. (2012). Continental Collision Slowing Due to Viscous Mantle Lithosphere rather Than Topography. Nature 483, 74-77. doi:10.1038/ nature 10848

Cowan, G. A., and Adler, H. H. (1976). The Variability of the Natural Abundance of 235U. Geo. et Cosmo. Acta 40, 1487-1490. doi:10.1016/0016-7037(76) 90087-9

EGPGYO (1989). "Yumen Oilfeld," in Petroleum Geology of China (In Chinese) 13 (Beijing, China: Petroleum Industry Press), 441.

Fang, X., Zhao, Z., Li, J., Yan, M., Pan, B., Song, C., et al. (2005). Magnetostratigraphy of the Late Cenozoic Laojunmiao Anticline in the Northern Qilian332w3 Mountains and its Implications for the Northern Tibetan Plateau Uplift. Sci. China Ser. D 48, 1040-1051. doi:10.1360/03yd0188

Galbraith, R. F., and Green, P. F. (1990). Estimating the Component Ages in a Finite Mixture. Int. J. Radiat. Appl. Instrument. D. Nucl. Tracks Radiat. Measure. 17, 197-206. doi:10.1016/1359-0189(90)90035-V

Gallagher, K., Brown, R., and Johnson, C. (1998). Fission Track Analysis and its Applications to Geological Problems. Annu. Rev. Earth Planet. Sci. 26, 519-572. doi:10.1146/annurev.earth.26.1.519

Garver, J. I., Brandon, M. T., Roden-Tice, M., and Kamp, P. J. J. (1999). Exhumation History of Orogenic highlands Determined by Detrital FissionTrack Thermochronology. Geol. Soc. Lond. Spec. Pub. 154, 283-304. doi:10. 1144/GSL.SP.1999.154.01.13

George, A. D., Marshallsea, S. J., Wyrwoll, K.-H., Jie, C., and Yanchou, L. (2001). Miocene Cooling in the Northern Qilian Shan, Northeastern Margin of the Tibetan Plateau, Revealed by Apatite Fission-Track and Vitrinite-Reflectance Analysis. Geol 29, 939-942. doi:10.1130/0091-7613(2001)029<0035: SSEOTE $>2.0 . \mathrm{CO} ; 2$

Gleadow, A. J. W., and Lovering, J. F. (1977). Geometry Factor for External Detectors in Fission Track Dating. Nucl. Track Detect. 1, 99-106. doi:10.1016/ $0145-224 x(77) 90003-5$
Guo, Z., Lu, J., and Zhang, Z. (2009). Cenozoic Exhumation and Thrusting in the Northern Qilian Shan, Northeastern Margin of the Tibetan Plateau: Constraints from Sedimentological and Apatite Fission-Track Data. J. Geol. 83, 562-579. doi:10.1111/j.1755-6724.2009.00045.x

Hu, X., Cao, X., Li, T., Mao, J., Zhang, J., He, X., et al. (2021). Late Quaternary Fault Slip Rate within the Qilian Orogen, Insight into the Deformation Kinematics for the NE Tibetan Plateau. Tectonics 40, e2020TC006586. doi:10.1029/ 2020TC006586

Hu, X., Chen, D., Pan, B., Chen, J., Zhang, J., Chang, J., et al. (2019a). Sedimentary Evolution of the Foreland basin in the NE Tibetan Plateau and the Growth of the Qilian Shan since 7 Ma. Geol. Soc. Am. Bull. 131, 1744-1760. doi:10.1130/ B35106.1

Hu, X., Wen, Z., Pan, B., Guo, L., and Cao, X. (2019b). Constraints on Deformation Kinematics across the Yumu Shan, NE Tibetan Plateau, Based on Fluvial Terraces. Glob. Planet. Change 182, 103023. doi:10.1016/j.gloplacha.2019. 103023

Hurford, A. J., and Green, P. F. (1981). A reappraisal of neutron dosimetry and uranium-238 $\lambda \mathrm{f}$ values in fission-track dating. Nuc. Tracks 5, 53-61. doi:10. 1016/0191-278X(81)90026-3

Jolivet, M., Brunel, M., Seward, D., Xu, Z., Yang, J., Roger, F., Tapponnier, P., Malavieille, J., Arnaud, N., and Wu, C. (2001). Mesozoic and Cenozoic tectonics of the northern edge of the Tibetan plateau: fission-track constraints. Tectonophysics 343, 111-134. doi:10.1016/S0040-1951(01)00196-2

Li, B., Zuza, A. V., Chen, X., Hu, D., Shao, Z., Qi, B., Wang, Z.-Z., Levy, D. A., and Xiong, X. (2020). Cenozoic multi-phase deformation in the Qilian Shan and out-of-sequence development of the northern Tibetan Plateau. Tectonophysics 782-783, 228423. doi:10.1016/j.tecto.2020.228423

Li, F. (2003). New evidences for the presence of the NS-trending extensional structures in northwestern China: An example from the Early Cretaceous halfgraben fault depressions in Jiuquan Gansu (in Chinese). Sedimentary Geology and Tethyan Geology 23 (2), 8. doi:10.3969/j.issn.1009-3850.2003.02.007

Li, Q., Pan, B., Hu, X., Hu, Z., Li, F., Yang, S., et al. (2013). Apatite fission track constraints on the pattern of faulting in the north Qilian Mountain. J. Earth Sci. 24, 569-578. doi:10.1007/s12583-013-0350-1

Li, Y., and Yang, J. (1998). Tectonic geomorphology in the Hexi Corridor, northwest China. Basin Res. 10, 345-352. doi:10.1046/j.1365-2117.1998.00070.x

Lin, X., Tian, Y., Donelick, R. A., Liu-Zeng, J., Cleber, S. J., Li, C. a., et al. (2019). Mesozoic and Cenozoic Tectonics of the Northeastern Edge of the Tibetan Plateau: Evidence from Modern River Detrital Apatite Fission-Track Age Constraints. J. Asian Earth Sci. 170, 84-95. doi:10.1016/j.jseaes.2018.10.028

Liu, B. (1980). Sedimentary Petrology (In Chinese). Beijing, China: Geology Publishing House, 45-48.

Liu, D., Yan, M., Fang, X., Li, H., Song, C., and Dai, S. (2011). Magnetostratigraphy of Sediments from the Yumu Shan, Hexi Corridor and its Implications Regarding the Late Cenozoic Uplift of the NE Tibetan Plateau. Quat. Int. 236, 13-20. doi:10.1016/j.quaint.2010.12.007

Métivier, F., Gaudemer, Y., Tapponnier, P., and Meyer, B. (1998). Northeastward Growth of the Tibet Plateau Deduced from Balanced Reconstruction of Two Depositional Areas: The Qaidam and Hexi Corridor Basins, China. Tectonics 17, 823-842. doi:10.1029/98TC02764

Molnar, P., England, P., and Martinod, J. (1993). Mantle Dynamics, Uplift of the Tibetan Plateau, and the Indian Monsoon. Rev. Geophys. 31, 357-396. doi:10. 1029/93RG02030

Palumbo, L., Hetzel, R., Tao, M., Li, X., and Guo, J. (2009). Deciphering the Rate of Mountain Growth during Topographic Presteady State: An Example from the NE Margin of the Tibetan Plateau. Tectonics 28, TC4017.1-TC4017.18. doi:10. 1029/2009TC002455

Pan, B., Chen, D., Hu, X., Cao, X., Chen, J., and Mao, j. (2016). Drainage Evolution of the Heihe River in Western Hexi Corridor, China, Derived from Sedimentary and Magnetostratigraphic Results. Quat. Sci. Rev. 150, 250-263. doi:10.1016/j. quascirev.2016.08.036

Pan, B., Gao, H., Li, B., and Li, J. (2004). Step-like Landforms and Uplift of the Qinghai-Xizang Plateau (In Chinese). Quat. Sci. 24, 50-58. doi:10.3321/j.issn: 1001-7410.2004.01.006

Pang, J., Yu, J., Zheng, D., Wang, W., Ma, Y., Wang, Y., et al. (2019b). Neogene Expansion of the Qilian Shan, north Tibet: Implications for the Dynamic Evolution of the Tibetan Plateau. Tectonics 38, 1018-1032. doi:10.1029/ 2018TC005258 
Pang, J., Yu, J., Zheng, D., Wang, Y., Zhang, H., Li, C., et al. (2019a). Constraints of New Apatite Fission-Track Ages on the Tectonic Pattern and Geomorphic Development of the Northern Margin of the Tibetan Plateau. J. Asian Earth Sci. 181, 103909. doi:10.1016/j.jseaes.2019.103909

Powers, M. C. (1953). A New Roundness Scale for Sedimentary Particles. Sepm Jsr 23, 117-119. doi:10.1306/D4269567-2B26-11D7-8648000102C1865D

Qi, B., Hu, D., Yang, X., Zhang, Y., Tan, C., Zhang, P., et al. (2016). Apatite Fission Track Evidence for the Cretaceous-Cenozoic Cooling History of the Qilian Shan (NW China) and for Stepwise Northeastward Growth of the Northeastern Tibetan Plateau since Early Eocene. J. Asian Earth Sci. 124, 28-41. doi:10.1016/j. jseaes.2016.04.009

Ren, Z., Liu, C., Zhang, X., Wu, H., Chen, G., Li, J., et al. (2000). Recovery and Comparative Research of thermal History on Jiuquan basin Group (In Chinese). Chin. J. Geophys. 43, 635-645. doi:10.1002/cjg2.82

Spencer, C. J., Prave, A. R., Cawood, P. A., and Roberts, N. M. W. (2014). Detrital Zircon Geochronology of the Grenville/Llano Foreland and Basal Sauk Sequence in West Texas, USA. Geol. Soc. America Bull. 126, 1117-1128. doi:10.1130/B30884.1

Steiger, R. H., and Jäger, E. (1977). Subcommission on Geochronology: Convention on the Use of Decay Constants in Geo- and Cosmochronology. Earth Planet. Sci. Lett. 36, 359-362. doi:10.1016/0012-821X(77)90060-7

Tapponier, P., Meyer, B., Avouac, J. P., Peltzer, G., Gaudemer, Y., Guo, S., et al. (1990). Active Thrusting and Folding in the Qilian Shan, and decoupling Between Upper Crust and Mantle in Northeastern Tibet. Earth Planet. Sci. Lett. 97, 382-407. doi:10.1016/0012-821x(90)90053-Z

Tapponnier, P., Zhiqin, X., Roger, F., Meyer, B., Arnaud, N., Wittlinger, G., et al. (2001). Oblique Stepwise Rise and Growth of the Tibet Plateau. Science 294, 1671-1677. doi:10.1126/science. 105978

Wagner, G. A., Gleadow, A. J. W., and Fitzgerald, P. G. (1989). The Significance of the Partial Annealing Zone in Apatite Fission-Track Analysis: Projected Track Length Measurements and Uplift Chronology of the Transantarctic Mountains. Chem. Geology. Isotope Geosci. Sec. 79, 295-305. doi:10.1016/0168-9622(89) 90035-3

Wan, J., Zheng, D., Zheng, W., and Wang, W. (2011). Modeling thermal History during Low Temperature by K-Feldspar MDD and Fission Track: Example from Meso-Cenozoic Tectonic Evolution in Saishiteng Shan in the Northern Margin of Qaidam Basin (In Chinese). Seismology Geology. 33, 370-382. doi:10. 3969/j.issn.0253-4967.2011.02.010

Wan, J., Zheng, W., Zheng, D., Wang, W., and Wang, Z. (2010). Low Closure Temperature Thermochronology Study on the Late Cenozoic Tectonic Active of Northern Qilian Shan and its Implication for Dynamics of Tibetan Plateau Growth (In Chinese). Geochimica 39, 439-446. doi:10.19700/j.0379-1726.2010. 05.004

Wang, W., Zhang, P., Pang, J., Garzione, C., Zhang, H., Liu, C., et al. (2016). The Cenozoic Growth of the Qilian Shan in the Northeastern Tibetan Plateau: A Sedimentary Archive from the Jiuxi Basin. J. Geophys. Res. Solid Earth 121, 2235-2257. doi:10.1002/2015JB012689

Wang, W., Zheng, D., Li, C., Wang, Y., Zhang, Z., Pang, J., et al. (2020). Cenozoic Exhumation of the Qilian Shan in the Northeastern Tibetan Plateau: Evidence from Low-Temperature Thermochronology. Tectonics 39, e2019TC005705. doi:10.1029/2019TC005705

Wang, W., Zheng, W., Zhang, P., Li, Q., Kirby, E., Yuan, D., et al. (2017). Expansion of the Tibetan Plateau during the Neogene. Nat. Commun. 8, 15887. doi:10. 1038/ncomms 15887

Wang, Y., Zheng, D., Pang, J., Zhang, H., Wang, W., Yu, J., et al. (2018). Using Slope-Area and Apatite Fission Track Analysis to Decipher the Rock Uplift Pattern of the Yumu Shan: New Insights into the Growth of the NE Tibetan Plateau. Geomorphology 308, 118-128. doi:10.1016/j.geomorph.2018. 02.006

Wen-Jun, Z., Hui-Ping, Z., Pei-Zhen, Z., Molnar, P., Xing-Wang, L., and DaoYang, Y. (2013). Late Quaternary Slip Rates of the Thrust Faults in Western Hexi Corridor (Northern Qilian Shan, China) and Their Implications for
Northeastward Growth of the Tibetan Plateau. Geosphere 9, 342-354. doi:10.1130/GES00775.1

Xu, Z., Yang, J., Li, H., Ji, S., Zhang, Z., and Liu, Y. (2011). On the Tectonics of the India-Asia Collision (In Chinese). Acta Geol. Sin. 85, 1-33.

Yang, S., Chen, H., Cheng, X., Xiao, A., He, G., and Chen, J. (2007). Deformation Characteristics and Rules of Spatial Change for the Northern Qilian Shan Thrust belt (In Chinese). Earth Sci. Front. 14, 211-221. doi:10.3321/j.issn:10052321.2007.05.021

Yin, A., and Harrison, T. M. (2000). Geologic Evolution of the Himalayan-Tibetan Orogen. Annu. Rev. Earth Planet. Sci. 28, 211-280. doi:10.1146/annurev.earth. 28.1.211

Yin, A., Rumelhart, P. E., Butler, R., Cowgill, E., Harrison, T. M., Foster, D. A., et al. (2002). Tectonic History of the Altyn Tagh Fault System in Northern Tibet Inferred from Cenozoic Sedimentation. Geol. Soc. Am. Bull. 114, 1257-1295. doi:10.1130/0016-7606(2002)114<1257:thotat $>2.0$. co;2

Yu, J., Pang, J., Wang, Y., Zheng, D., Liu, C., Wang, W., et al. (2019). Mid-Miocene Uplift of the Northern Qilian Shan as a Result of the Northward Growth of the Northern Tibetan Plateau. Geosphere 15, 423-432. doi:10.1130/GES01520.1

Yuan, D. Y., Ge, W. P., Chen, Z. W., Li, C. Y., Wang, Z. C., Zhang, H. P., et al. (2013). The Growth of Northeastern Tibet and its Relevance to Large-scale continental Geodynamics: A Review of Recent Studies. Tectonics 32, 1358-1370. doi:10.1002/tect.20081

Zhao, Z., Fang, X., and Li, J. (2001). Late Cenozoic Magnetic Polarity Stratigraphy in the Jiudong Basin, Northern Qilian Mountain. Sci. China Ser. D-earth Sci. 44, 243-250. doi:10.1007/BF02911993

Zhao, Z., Granger, D. E., Chen, Y., Shu, Q., Liu, G., Zhang, M., et al. (2017). Cosmogenic Nuclide Burial Dating of an Alluvial Conglomerate Sequence: An Example from the Hexi Corridor, NE Tibetan Plateau. Quat. Geochronol. 39, 68-78. doi:10.1016/j.quageo.2017.02.007

Zheng, D., Clark, M. K., Zhang, P., Zheng, W., and Farley, K. A. (2010). Erosion, Fault Initiation and Topographic Growth of the North Qilian Shan (Northern Tibetan Plateau). Geosphere 6, 937-941. doi:10.1130/GES00523.1

Zheng, D., Wang, W., Wan, J., Yuan, D., Liu, C., Zheng, W., et al. (2017). Progressive Northward Growth of the Northern Qilian Shan-Hexi Corridor (Northeastern Tibet) during the Cenozoic. Lithosphere 9, 408-416. doi:10.1130/L587.1

Zhu, X. (2008). Sedimentary Petrology. 4th edition. Beijing, China: Petroleum Industry Press, 23-24.

Zhuang, G., Johnstone, S. A., Hourigan, J., Ritts, B., Robinson, A., and Sobel, E. R. (2018). Understanding the Geologic Evolution of Northern Tibetan Plateau with Multiple Thermochronometers. Gondwana Res. 58, 195-210. doi:10.1016/ j.gr.2018.02.014

Zuza, A. V., Cheng, X., and Yin, A. (2016). Testing Models of Tibetan Plateau Formation with Cenozoic Shortening Estimates across the Qilian Shan-Nan Shan Thrust belt. Geosphere 12, 501-532. doi:10.1130/GES01254.1

Conflict of Interest: The authors declare that the research was conducted in the absence of any commercial or financial relationships that could be construed as a potential conflict of interest.

Publisher's Note: All claims expressed in this article are solely those of the authors and do not necessarily represent those of their affiliated organizations, or those of the publisher, the editors, and the reviewers. Any product that may be evaluated in this article, or claim that may be made by its manufacturer, is not guaranteed or endorsed by the publisher.

Copyright (c) 2022 Pan, Zhao, Hu, Zhang and Chen. This is an open-access article distributed under the terms of the Creative Commons Attribution License (CC BY). The use, distribution or reproduction in other forums is permitted, provided the original author(s) and the copyright owner(s) are credited and that the original publication in this journal is cited, in accordance with accepted academic practice. No use, distribution or reproduction is permitted which does not comply with these terms. 